\title{
Factors Affecting Saving Behaviors of the Ministry of Public Health Employees: A Case Study of the Faculty of Public Health and Allied Health Sciences, Praboromarajchanok Institute
}

\author{
Rujee Charupash ${ }^{1}$ \\ ${ }^{1}$ Sirindhorn College of Public Health Khon Kaen Province,Faculty of Public Health and Allied \\ Sciences,Praboromarajchanok Institue, Thailand
}

\begin{abstract}
.
A survey research which has the objective to study of saving behaviors and factors affecting saving behaviors of the Ministry of Public Health Employees. Used to the simple random sampling method which has 173 sample sizes and collecting data with questionnaires that tested content validation and reliability which sent by mail and received all of the questionnaires. Analyzed data by frequency, mean and Chi-Square test.

Results:

1.Gerneral characteristic; found that, the sample size was 173 , mostly female $(70.52 \%)$, the age between 31-40 years (36.99\%), single marital status group (50.87\%) and Ministry of Public Health Employee's position (54.91\%).

2. Factors affecting saving behaviors; found that, 1) personal factors (male) and single marital status group are significantly to the amount of saving behavior of « 5000-baht at level 0.05. 2) the economic factors, the group who has income $<10,000$ - baht is significantly to the amount of saving behavior of < 5000-baht at level 0.05 and the group who has income < 10,000-15,000 baht is significantly to the purpose of saving money for tax deduction at level 0.05 . And 3 ) the position factor in the Ministry of Public Health Employees is significantly to the amount of saving behavior of $<5000$-baht and the purpose of saving money for future funding sources and children's education fund at level 0.05 .

Suggestion: Colleges should be provided knowledge and promote the various saving money methods. Including guidelines for actual management of incomes and debt.
\end{abstract}

Keywords: saving behaviors, factors affecting 


\section{$2^{\text {nd }}$ International Conference on Research in TEACHING and EDUCATION}

\section{Introduction}

From the survey of the Thailand National Statistical Office (2016) found that, at the household level, there is saving up to $66.7 \%$, with most method of allocating from the remaining money from spending. For the purpose of saving, the first priority is to spending for old age and retirement, followed by saving for emergency used or illness which used most of saving by cash $(45.1 \%)$, followed by saving in the bank $(38.7 \%)$. The method saving by investing such as bond, stock, mutual fund are not yet popular , the saving money is mostly from salary /fix income (38.0\%). There are many studies on saving money behaviors of people group, the official government and the government employees ,such as; 1) Kanokwan Vichien (Vichien ,2012( The studied of Saving Behavior's the official government and the permanent employees of Srinaharinwirot University found that ,the samples group had saving behaviors with average amount of saving per month less than or equal to 20,000 baht and had the most saving through the commercial bank. The economic factors, the average incomes and debt per month were significantly level at 0.05 . 2) Rujee Charupash (Charupash ,2017) The studied of Saving Behavior for retirement of the official government who worked at Sirindhorn Colleges of Public Health found that, Aging factor of the age between 50-55 years which had saving behaviors more than other group by using the form of real-estate (house, land and buildings etc.). As for the single, the behaviors of saving in the amount of less than 5,000 baht/month, more than others group. As for job position factors, the lecture group had saving behaviors with form of saving on real-estate (house, land and buildings etc.) more than others group.

There are many studies on saving money behaviors of people group, the official government and the government employees ,such as; 1) Kanokwan Vichien (Vichien ,2012)

The studied of Saving Behavior's the official government and the permanent employees of Srinaharinwirot University found that the samples group had saving behaviors with average amount of saving per month less than or equal to 20,000 baht and had the most saving through the commercial bank. The economic factors, the average incomes and debt per month were significantly level at 0.05. 2) Rujee Charupash (Charupash ,2017) The studied of Saving Behavior for retirement of the official government who worked at Sirindhorn Colleges of Public Health found that, Aging factor of the age between 50-55 years which had saving behaviors more than other group by using the form of real-estate (house, land and buildings etc.). As for the single, the behaviors of saving in the amount of less than 5,000 baht/month, more than others group. As for job position factors, the lecture group had saving behaviors with form of saving on real-estate (house, land and buildings etc.) more than others group.

Therefore, the researcher interested to study the individual of saving behaviors of the Ministry of Public Health Employees who work at the Sirindhorn College of Public health under the Faculty of Public Health and Allied Health Sciences. How are they saving behaviors? which both of the amount of saving, the purpose of saving money and the form of saving. Due to take the results for the future determine saving money and creating the value of saving knowledge and value of spending. Otherwise, it is the self of financial planning in order to guarantee the working life of the working age and it is also information for policy of the director to prepare the retirement of this group. 


\section{$2^{\text {nd }}$ International Conference on Research in \\ TEACHING and EDUCATION}

RLCONF

6-8 March, 2020

BUDAPEST,HUNGARY

\section{Objective}

1.To study saving behaviors of the Ministry of Public Health Employees such as; the amount of saving money/month, purpose of saving and form of saving

2.To study factors affecting behaviors of the Ministry of Public Health Employees

\section{Benefit of this study}

For the Ministry of Public Health Employees in future determine saving money and creating the value of saving knowledge and value of spending and it is also information for policy of the director to prepare the retirement of this group.

\section{Conceptual Framework}

\section{Independent Variables}

\section{Dependent Variables}

\section{Methodology}

1.This is the Survey Research

2.Population and Sample Size

\section{Saving Behaviors}

1.the amount of money/month

2.Form of Savings

-deposit of commercial banks,

the Cooperating Saving

Organization

-Investment (stocks, Mutual

Funds (LTF,RMF)) and

Government Bonds)

1.Individual factors (gender, age, marital status and job position)

2.Economic factors (the average of income/month, the average of expenses /month)

-Buying life insurances lottery etc.

-Buying the real -estate (house, land and building etc.

-Provident fund member,

Social Security fund

-Other (gold, car, amulets etc.)

3.Purpose of savings

-to be the reserve source future

-to be funding of children

-to spend an emergency spend

-to buy things which needed in short term

-to buy the assets or the inheritance

-to tax deduction 


\section{$2^{\text {nd }}$ International Conference on Research in TEACHING and EDUCATION}

RTECONF

6-8 March, 2020

BUDAPEST,HUNGARY

Population: The Ministry of Public Health Employees who work at colleges of the Faculty of Public Health and Allied Health Sciences, Praboromarajchanok Institute in fiscal year 2018 with a term of less than 1 year, total of 305 people.

Sample Size: Calculate sample size using Yamane's formula for simple random sampling ( significant level $=0.05$ ) and the calculation results of the sample $=173$.

3. Tools and correcting data 3.1 Used questionnaires which applied from the research's questionnaires of Anongnut Teinthong and Kunyarat Wongsompoo

(Teinthong \& Wongsompoo ,2011), follows as;

Part 1 General data (personal factors such as; gender, age, marital status, job position.

Part 2 Economic factors (The average of incomes/month, The average of expenditure/month(.

Part 3 Saving Behaviors follows as;

-the amount of money /month

-form of savings (deposit in commercial bank or the Cooperating Saving

Organization,Investment (stock, mutual funds (LTF, RMF), government bonds, buying life Insurances lottery etc., buying the real-estate (house, land and buildings etc.), provident fund member, Social Security fund and other as; gold, car, amulets etc.

- purpose of savings (To be the reserve source future, to be funding of children, to spend an emergency spend, to buy things which needed in short term, to be the asset or the inheritance and to reduce tax)

3.2 Correcting data by using the questionnaires which passed the Content Validity test and Reliability test $=0.712$, then send the questionnaires by post.

3.3 Data analyzed by descriptive statistic (frequency, mean) and Inferential Statistic (Chi-Square), by significance level $=0.05$.

\section{Results}

1. General data

Amount of 173 's the sample size which found that; Mostly are female (70.52\%(, age between 31-40 years (36.99\%), marital status (50.87\%) and the Ministry of Public Health Employees position $(54.91 \%)$ respectively.

2. Factors affecting saving behaviors (the amount of money /month, form of saving and purpose of saving) of the Ministry of Public Health Employees.

2.1 General factors affecting saving behaviors which found that;

2.1.1 Male and marital status were significantly related the amount of money less than 5,000 baht at level 0.05 .

2.1.2 All of factors were not significantly related to purpose of saving money.

3. The economic factors affecting saving behaviors (the amount of money /month, form of saving and purpose of saving) of the Ministry of Public Health Employees which found that;

The group that has incomes $<10,000$ - baht is significantly to the amount of saving behaviors of $<5000$-baht at level 0.05 and the group that has incomes < 10,000- 15,000- baht is significantly to the purpose of saving money for tax deduction at level 0.05 .

4.The position factor in the Ministry of Public Health Employees which found that; 


\section{$2^{\text {nd }}$ International Conference on Research in TEACHING and EDUCATION}

RTECONF

6-8 March, 2020

BUDAPEST,HUNGARY

The position factor in the Ministry of Public Health Employees (permanent employees) is significantly to the amount of saving behavior of $<5,000$-baht and the purpose of saving money for future funding sources and children's education fund at level 0.05.

\section{Discussion}

Factors affecting saving behaviors of the Ministry of Public Health Employees found that Male and marital status were significantly related the amount of money less than 5,000 -baht. It may be that having single status and being male means, they do not consider to saving so much, resulting in a saving less than 5,000 -bath at level 0.05 .

The economic factors affecting saving behaviors in the group that has incomes $<10,000$ - baht is significantly to the amount of saving behavior of $<5,000$-baht at level 0.05 and the group that has incomes $<10,000-15,000$ - baht is significantly to the purpose of saving money for reduced tax at level 0.05 .This may be due to low income, so they have not any money for saving and this result consistent with the study result of Kanokwan Vichien (Vichien ,2012) which found that the general factors (gender, age, type of personal) and economic factors which had average incomes 20,000- baht/month with significant at level 0.05 . But the results of this study which found that the group who has income $<10,000$-baht is significantly to purpose of reduce tax at level 0.05 which is not consistent with the results of study of Kittipast Lerdsongkarm (Lerdsongkarm ,2012) which found that most real estate company employees who have less than 5,000 -baht with the aim of saving for emergency use.

For the position factor in the Ministry of Public Health Employees (permanent employees) is significantly to the amount of saving behaviors of $<5,000$-baht and the purpose of saving money for future funding sources and children's education fund at level 0.05 are consistent with the study results of Kanokwan Vichien (Vichien ,2012) which found that personal type is related to purpose of saving of the government official and the employees of Srinaharinwirot University and the study results of Chanaporn Prapakit (Prapakit ,2009) which found that the personnel under the Bureau of the Royal Household have gender, status and monthly expenses ,different people have different saving behaviors. As for personnel under the Bureau of the Royal Household, with different job positions, monthly debt has saving behaviors.

\section{Conclusion}

The results of this study indicate that the majority of the respondents have relatively low incomes (not more than 10,000 -baht). They are the Ministry of Public Health Employees. Therefore, they will have money less than 5,000 -baht. So, they will save money by deposit bank or the Cooperating Saving Organization, because they believed that it is safe and convenient, and most of them are member of the Cooperating Saving Organization to have the right to find the loan for easy use in the various needs. Therefore, they do not care and seek to knowledge of investment that will receive more return than saving in commercial banks or saving the Cooperating Saving Organization. In addition, these samples have saving in form of 


\section{$2^{\text {nd }}$ International Conference on Research in TEACHING and EDUCATION}

RLCONF

6-8 March, 2020

BUDAPEST,HUNGARY

welfare provided by government such as Social Security fund, Provide fund etc. However, it should be noted from the results of this study that the sample group have saving for purpose tax deduction, which issue of the administrators of the colleges should attention to promote knowledge.

\section{Recommendation}

Should study of the spending behavior before saving of the Ministry of Public Health Employees, will able to find ways to help to balance incomes and expenses until more money

left to save enough to be use when they retried. And the Colleges should provide knowledge on commercial spending debt reduction and promoting savings through various method by creating policies and practical methods.

\section{Acknowledgement}

The researcher will thank the Sirindhorn College of Public Health Khon Kaen Province for supporting the budget for conducting this research and the all of sample group who cooperate questionnaires

\section{References}

[1]Charupash,Rujee .(2018). The study of Saving Behavior for retirement of the official government who worked at Sirindhorn Colleges of Public Health, Khon Kaen Publich, pp. Abstract.

[2]Lerdsongkarm ,Kittipast . (December 2018). Saving Behaviors of the real estate company employees. Master of Economic Thesis Economic Development of Srinaharinwirot University. [Online]. pp.28. Available: thesis.swu.ac.th/swuthsis.swu.ac.th/swuthesis/Hum_Res_Econ/Kritapas_L.pd.

[3]Prapakit, Chanaporn (December 2018). The study of Saving Behaviors of the personnel under the Bureau of the Royal Household . [Online]. pp. Abstract. Available: www.dpu.ac.th/graduate/upload/conent/files/.../6_Jur_V3_NO_2pdf.

[4]The Thailand National Statistical Office (December 2018). Thai household Savings. [Online]. pp.1. Available:www.nso.go.th/sites/2014/DocLib13/Socila/incomes/saving household/quarter 4_2016.pdf.

[5] Teinthong,Anongnut \& Wongsompoo ,Kunyarat the study of Behaviors and form of Saving of employees of finiacial insititions and government officers in Udor tani province. [Online]. Pp.236-247. Available https://rtt.kku.ac.th/ejournal/pa_upload_pdf/451751.pdf.

[6]Vichien, Kanokwan .( December 2018). The study of Saving Behavior's the official government and the permanent employees of Srinaharinwirot University. [Online]. pp.25. Available: cms.swu.ac.th/Portals/research/55/49.pdf. 